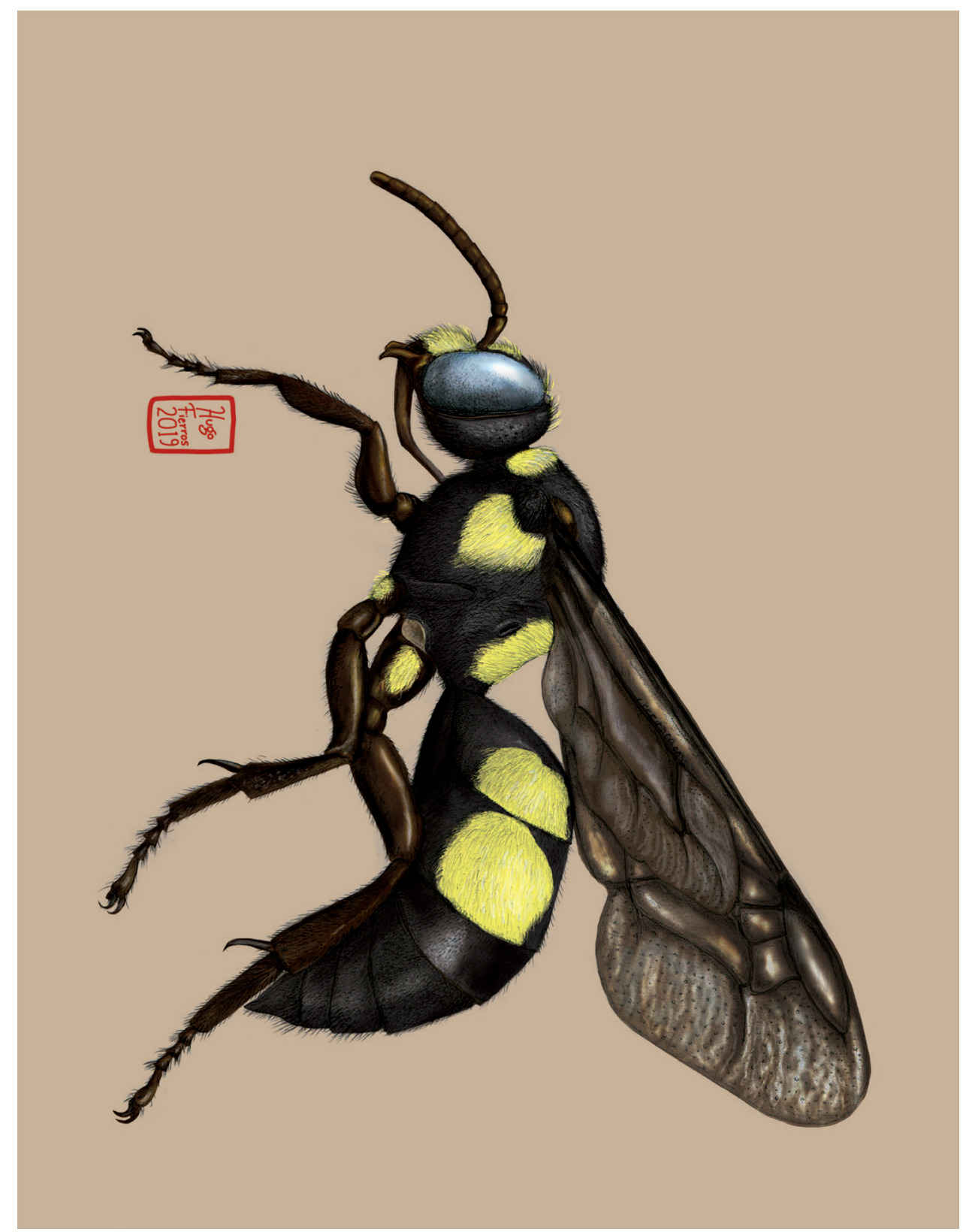

Dugesiana, Año 27, No. 1, enero 2020-junio 2020 (primer semestre de 2020), es una publicación semestral, editada por la Universidad de Guadalajara, a través del Centro de Estudios en Zoología, por el Centro Universitario de Ciencias Biológicas y Agropecuarias. Camino Ramón Padilla Sánchez \# 2100, Nextipac, Zapopan, Jalisco, Tel. 37771150 ext. 33218, http://148.202.248.171/dugesiana/index.php/DUG/index, glenusmx@gmail.com. Editor responsable: José Luis Navarrete-Heredia. Reserva de Derechos al Uso Exclusivo 04-2009-062310115100-203, ISSN: 2007-9133, otorgados por el Instituto Nacional del Derecho de Autor. Responsable de la última actualización de este número: José Luis Navarrete-Heredia, Editor y Ana Laura González-Hernández, Asistente Editorial. Fecha de la última modificación 1 de enero 2020, con un tiraje de un ejemplar.

Las opiniones expresadas por los autores no necesariamente reflejan la postura del editor de la publicación.

Queda estrictamente prohibida la reproducción total o parcial de los contenidos e imágenes de la publicación sin previa autorización de la Universidad de Guadalajara. 


\title{
New species of the genus Ectinogonia Spinola, 1837 (Coleoptera: Buprestidae: Dicercini) from Southern Andes of Peru
}

\author{
Nueva Especie del género Ectinogonia Spinola, 1837 (Coleoptera: Buprestidae: Dicercini) de los An- \\ des Sureños de Perú
}

\section{Alfredo Edgardo Giraldo-Mendoza}

Museo de Entomología Klaus Raven Büller. Universidad Nacional Agraria La Molina. Av. La Molina s/n. Apartado Postal 12-056. Lima, Perú. aegmendoza@gmail.com

\begin{abstract}
A new species of the genus Ectinogonia Spinola, 1837 of southern Peruvian Andes is described and illustrated: Ectinogonia (Ectinogonia) toratensis sp. nov. Diagnostic characters are discussed in relation to Chilean species, particularly those distributed north of $30^{\circ} \mathrm{S}$.
\end{abstract}

Key words: Jewel beetles, Neotropics, South America, Systematics.

\section{RESUMEN}

Una nueva especie del género Ectinogonia Spinola, 1837 de los Andes sur-peruanos es descrita e ilustrada: Ectinogonia (Ectinogonia) toratensis sp. nov. Los caracteres diagnósticos se discuten en relación con las especies de Chile, en particular aquellas distribuidas al norte de $30^{\circ} \mathrm{S}$.

Palabras clave: Bupréstidos, Neotrópico, Sudamérica, Sistemática.

Under the current definition, the South American genus Ectinogonia Spinola, 1837 includes species recorded from Argentina, Bolivia, Brazil, Chile and Peru (Bellamy 2006, 2008). These are phytophagous, free-living adults and endophytic larvae, associated with at less eight families and eleven genera of host plants (Cobos 1953, Moore 1994).

First revisionary work by Cobos (1953) was focused on Chilean species and recognized only four species, since the author assigned subspecies rank to most previously described species. Moore (1994) refutes previous species concepts, revalidating eight species, describing five new species and offering an updated key, making a total of seventeen species and three subspecies. Later, Moore and Vidal (2015) contributed to the knowledge of Chilean Ectinogonia providing re-descriptions, diagnosis, habitus images, key to species, distributional maps and ecological data for species and subspecies known until then. Recently, three new species were described based on specimens from northern and central Chilean localities (Anguita-Salinas et al. 2017; Moore 2017; Moore and Guerrero 2017). Also, some nomenclatural changes for central Chilean species have been suggested from phylogenetic studies (Anguita-Salinas et al. 2019).

Regarding to single species recorded from Argentina and Brazil respectively, these remain questionable until the type specimens could be properly studied (Bellamy 2006). Two known species of Bolivia and Peru belong to the sub- genus Kheiliella Obenberger, 1940, recently revalidated by Moore and Dieguez (2014). This subgenus includes the Peruvian species Ectinogonia (Kheiliella) bellamyi Moore and Dieguez, 2014 and Ectinogonia (Kheiliella) melichari Obenberger, 1923 with Bolivian nominal subspecies and two Peruvian subspecies described by Cobos $(1953,1969)$.

In the present work, the first Peruvian species of the subgenus Ectinogonia is described. Description is based on specimens recently collected during environmental surveys in southern Andes of Peru.

\section{MATERIALS AND METHODS}

Type specimens were deposited in entomological collection of Museo de Entomología Klaus Raven Büller, Universidad Nacional Agraria La Molina, Lima, Perú (MEKRB). Morphological terminology follows the most comprehensive and recent treatments of the genus Ectinogonia (Moore 1994, Moore and Vidal 2015).

Type specimen was photographed with a Canon EOS Rebel T5i DSLR, equipped with Macro lens and rail. Each image includes a series of photos taken in different planes, which were stacked with the Helicon focus 5.1 software. The male genitalia was extracted, treated for 10 minutes in $20 \% \mathrm{KOH}$, washed with distilled water and adhered to a small piece of cardboard. Drawings were made by impressions of photographs, observations with stereomicroscope and improvements with graphic design software. The 
geographical distribution was mapped using the free access program SimpleMappr (Shorthouse 2010).

\section{RESULTS AND DISCUSSION}

Ectinogonia (Ectinogonia) toratensis Giraldo, new species http://zoobank.org/85727559-CED0-4FCC-8AAE-

$$
\text { 17F96B79C0A7 }
$$

(Figures 1, 2, 3, 4, 5)

Diagnosis. Pronotum with elliptical, narrow and deep medial discal depression; surface coarsely punctated, sparser on upper edges of discal protrusions, coalescent or even wrinkled in medial discal depression and on sides of disc; lateral margins strongly crenulated; basal angles acute and protruding. Elytra without conspicuous pilosity; anterolateral margins strongly crenulated; costae not disrupted, with isolated punctures; overall surface with three kinds of punctuation: coalescent or even clustered on humeral area and surface between margin and third costa, coarse punctures arranged in rows adjacent to costae, and sparsely fine punctures between coarse punctures.

The new species should be assigned to the nominal subgenus of Ectinogonia because pronotum bears irregular distribution and size of punctures and an elliptical deep discal depression; elytra without humeral foveae nor laterally pubescent margins; parameres with apical third curved inward
(Moore and Dieguez 2014).

Description. Holotype, Male (Figure 1). Total Length: $21,5 \mathrm{~mm}$, Maximum width (at elytral base): 7,5 mm. Overall coloration black, head and pronotum glossy, elytra matted with a slight coppery tone; ventral surface with blue, green and violet metallic reflections in anterior margin of prosternum, epipleura, tibiae and tarsi. Head: depressed frons, with a widened longitudinal carina on upper half; surface finely punctuated, very dense or even wrinkled; internal margins of eye covered with dense and long white pilosity; eyes separated by a dorsal interocular distance equals to 2,0 times eye diameter; antennae reaching anterior third of pronotum, first globular, second and third as wide as long, fourth longer than wide, fifth slightly elongated and expanded, sixth to eleventh laterally expanded (lobed), apical reaching anterior third of pronotum. Pronotum: anterior margin bisinuate; discal protrusions raised and thick extending from anterior margin to base; lateral margins crenulate, wider at anterior half; posterior angles acute and protruding; medial discal depression narrowing towards anterior margin of pronotum; punctuation coarse, sparse in upper edge of discal protrusions, coalescent or even vermiculated in medial fovea and on both sides of disc; covered with scarce pilosity. Scutellum small, wider than long and deep. Elytra: anterolateral margins strongly
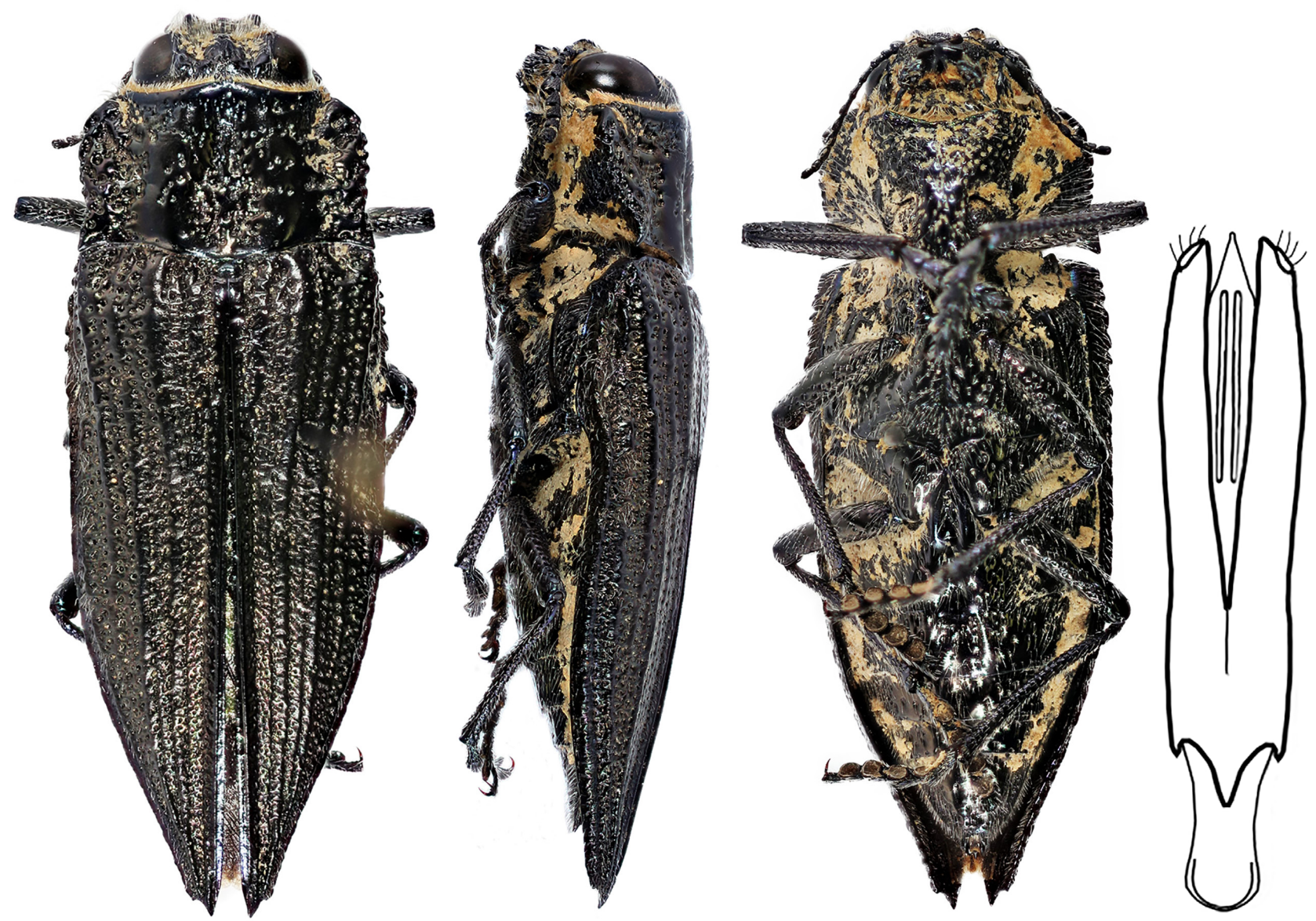

Figures 1-4. Ectinogonia (Ectinogonia) toratensis, male holotypus: 1) dorsal habitus, 2) lateral view, 3) ventral habitus view, 4) aedeagus, dorsal view. 

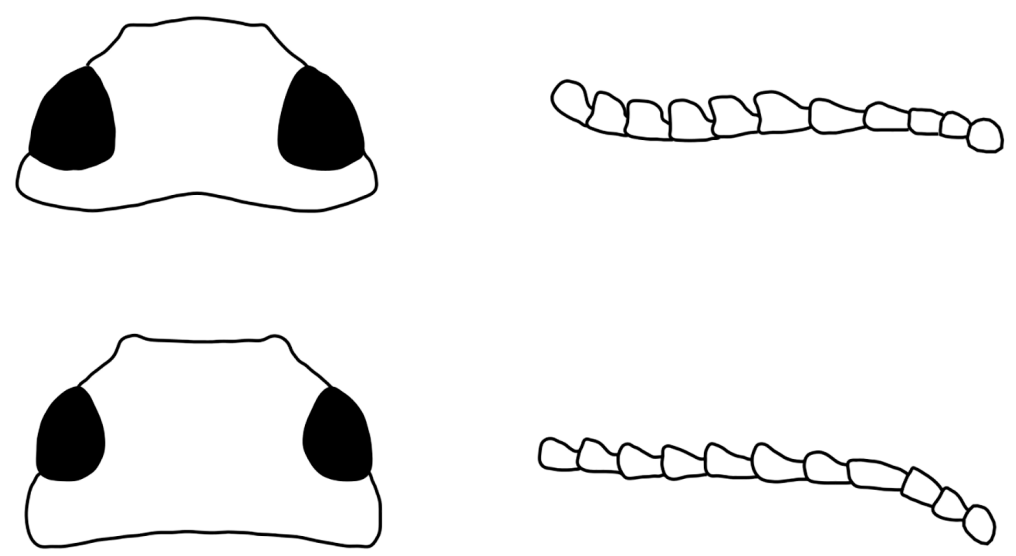

a)

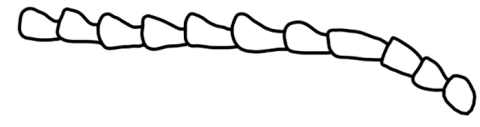

b)
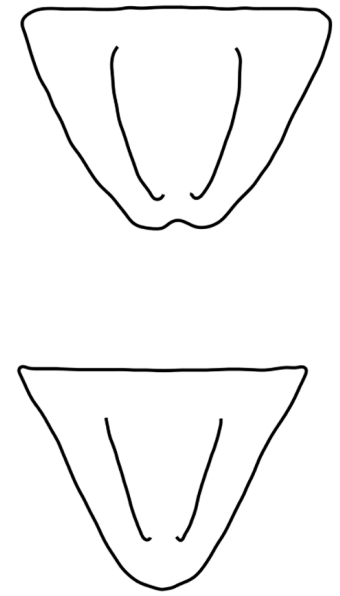

c)

Figure 5. Ectinogonia (Ectinogonia) toratensis, dimorphic characters in males (upper row) and females (lower row): a) dorsal interocular distance, $\mathrm{b}$ ) sixth to eleventh antennomeres, c) last abdominal sternite.

crenulated, lateral margins narrowed from posterior third to apex, apically irregular but not serrated, apex with long internal teeth; overall surface with three kinds of punctuation: coalescent or even clustered on humeral area and surface between margin and third costa (Figure 2), coarse punctures arranged in rows adjacent to costae, and sparse fine punctures between coarse punctures; distance between coarse punctures equals half of puncture diameter, fine punctures separated at least by puncture diameter; elytral costae complete, but somewhat distorted by coarse intercostal sculpture, only with isolated fine punctures; with scarce pilosity. Ventral surface covered with white, decumbent and dense pilosity on sides of abdominal sternites; last abdominal sternite with a small medial notch on apex; tibiae covered with short, white pilosity (Figure 3). Aedeagus: Length 3,5 mm, basal lobe longer than wide, with rounded apex; parameres parallel in basal third, slightly sinuate in apical two thirds; sensorial apex of each paramere concave and with four long setae; median lobe apically acuminate, ending in a sharp tip (Figure 4).

Description of female paratype. Total Length: 24,0 $\mathrm{mm}$, Maximum width: $8,5 \mathrm{~mm}$. Similar to male except for greater dorsal interocular distance (3,0 times eye diameter), antennae with sixth to eleventh antennomeres slightly expanded, last abdominal sternite rounded apically (Figure 5).

Variation: Paratypes (three males and seven females) very similar to holotype, except for slight differences on body size and ventral metallic reflection intensity observed in specimens of both sexes. Total Length $(n=10): 16,0-$ 24,0 mm; Maximum width: 5,5 - 8,5 mm.

Type material. Holotype male from PERU, Moquegua, Mariscal Nieto, Torata, $2840 \mathrm{~m}$, fondo de quebrada, hand collecting, 1655'02.87’S 7059'01.05’W, 03-II-2019, J. Ugarte (MEKRB). Female paratype with same label data as holotype (MEKRB). Two male paratypes with same la- bel data as holotype (MEKRB). Five female paratypes with same label data as holotype except for the date XI-2018 (MEKRB). One female paratype from PERU, Moquegua, Mariscal Nieto, Moquegua, $2940 \mathrm{~m}$, cardonal, pitfall traps, 16 53 '45.32'S 7101'54.27'W, XI-2018, J. Ugarte (MEKRB). One male paratype from PERU, Moquegua, Mariscal Nieto, Torata, $2900 \mathrm{~m}$, cardonal, pitfall traps, 1654'09.26”S 7059'24.72'W, 03-II-2019, J. Ugarte (MEKRB). One female paratype from PERU, Moquegua, Mariscal Nieto, Torata, Ilubaya, $2863 \mathrm{~m}$, matorral espinoso, hand collecting, $17^{\circ} 02^{\prime} 57.96$ 'S $70^{\circ} 49^{\prime} 41.05^{\prime} \mathrm{W}$, IX-2015, Y. Callohuari (MEKRB).

Etymology. The specific name refers to Torata district, where most of the known specimens of this species were found.

Biology. Specimens were found in ravines or slopes covered with two kinds of xeric vegetation: "cardonal" dominated by columnar cactus of species Browningia candelaris (Meyen) Britton \& Rose, 1920 and thorny scrub, a mixture of deciduous and evergreen shrubs (Figure 6). Most specimens were caught by hand collecting, some with pitfall traps. Host-plant associations are unknown.

This species bears yellowish waxy exudates on body surface, accumulated in frontal depressions of head, anterior angles of pronotum, prosternum, mesosternum and sides of abdominal sternites. Similar accumulations of waxy exudates have been previously described for three Chilean species: E. angulicollis (Fairmaire and Germain, 1858), E. pretiosa (Philippi, 1859) and E. pulverea Kerremans, 1919 (Moore and Vidal, 2015).

Distribution. Only known from western Andean range of Moquegua department, Mariscal Nieto province, Moquegua and Torata districts in southern Peru (Figure 7).

Taxonomic comments. According to key presented by Moore and Vidal (2015), E. toratensis is most similar to $E$. 


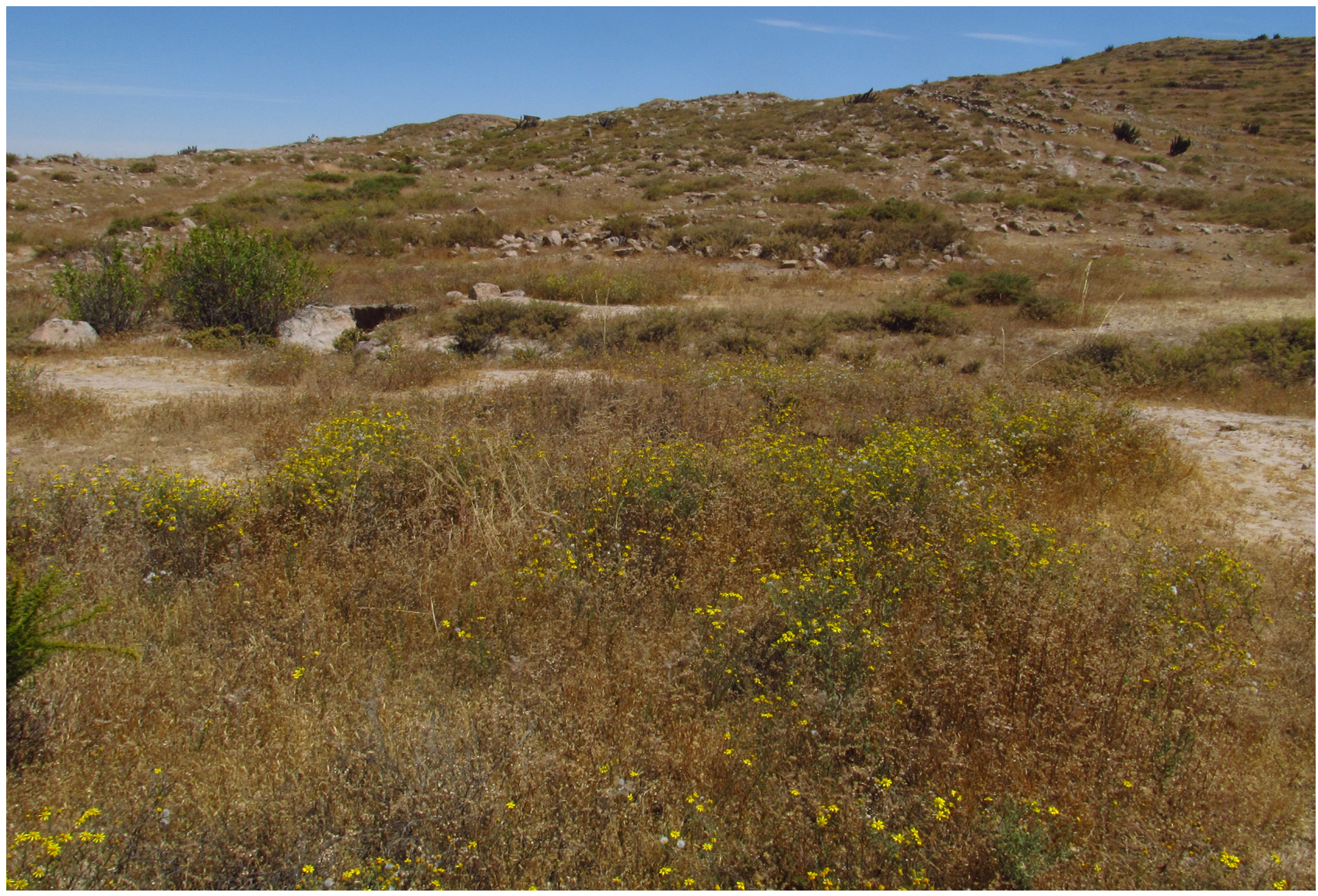

Figure 6. Thorny scrub vegetation at Ilubaya, 2863 m (Moquegua, Peru).

atacamensis Moore, 1994 known from Atacama and Coquimbo regions of Chile. However, E. atacamensis differs externally because posterior pronotal angles are hardly protruding and anterolateral elytral margins are scarcely crenulated. Further, aedeagus has parameres straight and parallel along its entire length and sensorial apex of parameres with many long setae (Moore and Vidal 2015, Figures 27, 28).

E. angulicollis (Fairmaire and Germain, 1858) and E. pretiosa (Philippi, 1859) from northern Chilean provinces $\left(19^{\circ}\right.$ to $\left.28^{\circ} \mathrm{S}\right)$ have a general appearance very similar to $E$. toratensis. But in the first species, dorsal and ventral body surfaces are densely covered with white pilosity, while the second species, have very singular pilosity clusters over elytral costae.

The widely distributed E. pulverea Kerremans, 1919 $\left(18^{\circ}\right.$ to $\left.30^{\circ} \mathrm{S}\right)$ has scarce intercostal sculpture, only with isolated rounded punctures, very different from what was seen in the new species.

E. toratensis is the first species of the subgenus Ectinogonia described for Peru. Two previously recorded Peruvian species belong to the subgenus Kheiliella. Therefore, new species is clearly distinguished from them by the diagnostic characters observed in pronotum, elytra, and parameres of both subgenera (Cobos 1953, Plate IV - Figure 10; Moore and Dieguez 2014, Figures 1-5).

\section{ACKNOWLEDGEMENTS}

To Clorinda Vergara for support this work at MEKRB. To Yony Callohuari for taking photographs of type specimens and providing an image of his field survey at Ilubaya. Also, to two anonymous reviewers for the suggestions that improved the original manuscript.

\section{LITERATURE CITED}

Anguita-Salinas, S., R. M. Barahona-Segovia, E. Poulin and A. Zúñiga-Reinoso. 2017. Genetic and morphological evidence for a new cryptic species of Ectinogonia (Coleoptera: Buprestidae) from central Chile. Zootaxa, 4303 (2): 284-292.

Anguita-Salinas, S., R. M. Barahona-Segovia, E. Poulin and A. Zúñiga-Reinoso. 2019. Taxonomic and systematic implications of the revision of the phylogenetic relations in the genus Ectinogonia Spinola 1837 (Coleoptera: Buprestidae) of central Chile. Zootaxa, 4603 (1): 159-171.

Bellamy, C. L. 2006. The systematic position of certain South American buprestid genera (Coleoptera: Buprestidae). The Coleopterists Bulletin, 60(2): 192-196.

Bellamy, C.L. 2008. A World Catalogue and Bibliography of the Jewel Beetles (Coleoptera: Buprestoidea), Volume 2: Chrysochroinae: Sphenopterini through Buprestinae: Stigmoderini. Pensoft Series Faunistica No. 77, Sofia, Moscow. 


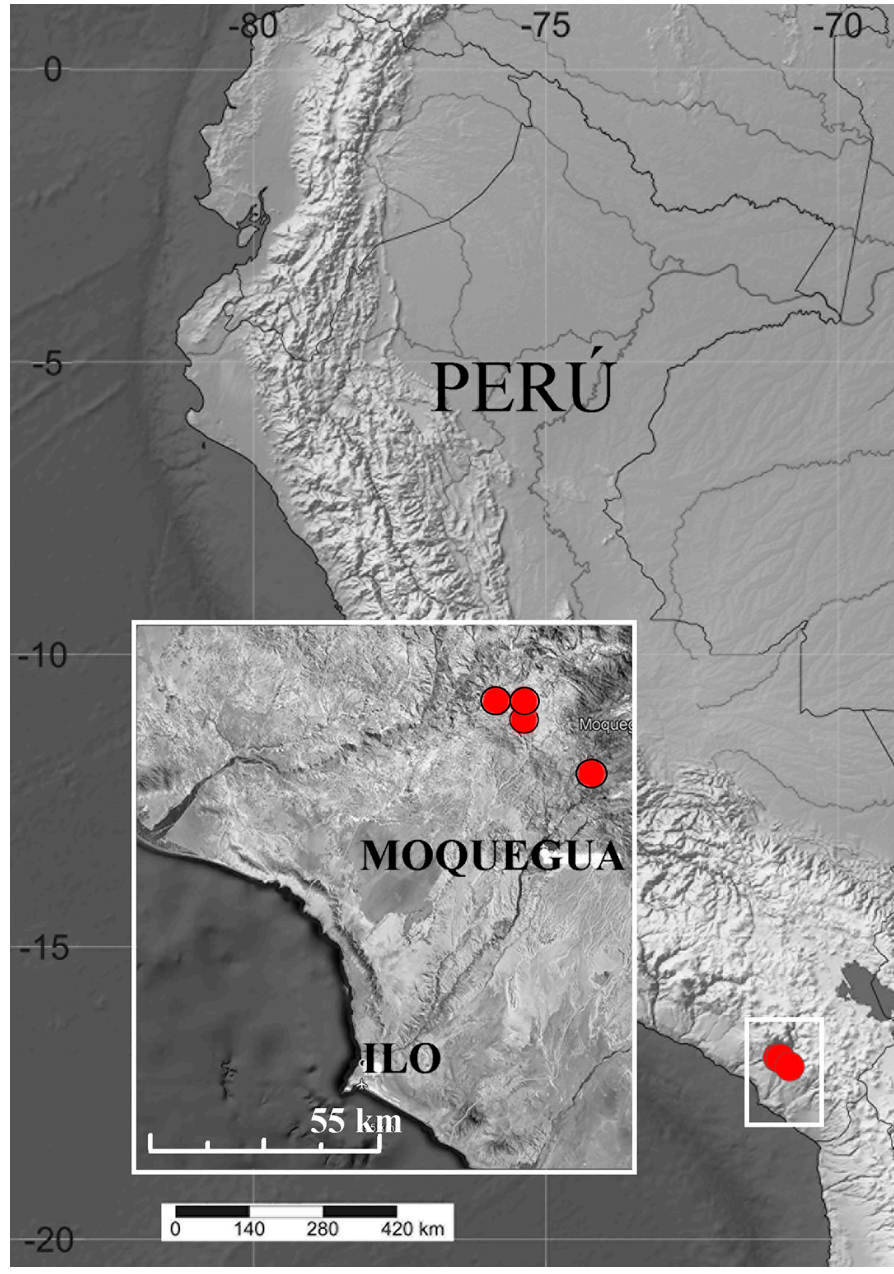

Figure 7. Distribution map of Ectinogonia (Ectinogonia) toratensis.
Cobos, A. 1953. Revisión de las Ectinogonia Spinola sensu strictus Coleoptera, Buprestidae. Revista Chilena de Entomología, 3: 41-68.

Cobos, A. 1969. Notas sobre bupréstidos neotropicales: XVII. Especies y subespecies nuevas (Coleoptera). Eos, Revista Española de Entomología, 44(14): 19-43.

Moore, T. 1994. Revisión del género Ectinogonia Spinola para Chile. Boletín de la Sociedad de Biología de Concepción, Chile, 65: 153-166.

Moore, T. 2017. Ectinogonia barrigai nov.sp.: primera especie de bupréstido del Monumento Natural Paposo Norte, Región de Antofagasta, Chile (Coleoptera: Buprestidae). Revista Chilena de Entomología, 42: 5-10.

Moore, T. and V. Dieguez. 2014. A contribution to the knowledge of Neotropical Buprestidae: Description of a new species of Ectinogonia Spinola (Coleoptera: Buprestidae: Chrysochroinae: Dicercini). The Coleopterists Bulletin, 68(1): 47-49.

Moore, T. and M. Guerrero. 2017. Nueva especie del género Ectinogonia Spinola (Buprestidae: Dicercini) de la Cordillera de los Andes de Chile Central. Revista Chilena de Entomología, 43: 5-10.

Moore, T. and P. Vidal. 2015. Los Bupréstidos de Chile. Editorial Universidad Católica, Santiago, Chile.

Shorthouse, D. P. 2010. SimpleMappr, an online tool to produce publication-quality point maps. http:// www.simplemappr.net. Fecha de consulta: 19 de Junio de 2019.

Recibido: 11 de julio 2019

Aceptado: 21 de septiembre 2019 